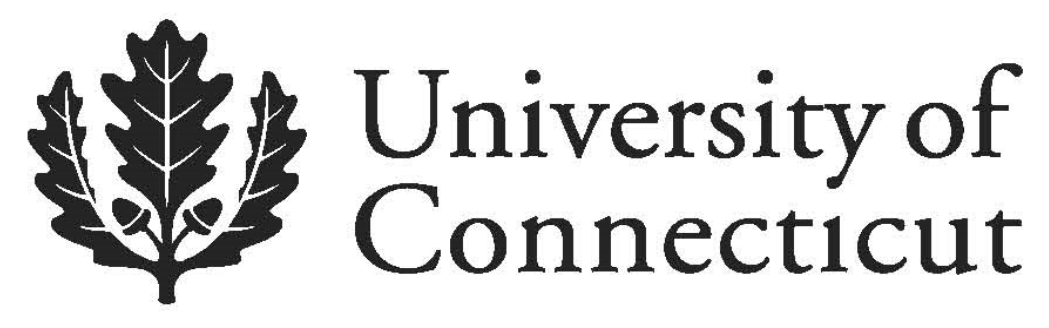

Department of Economics Working Paper Series

\title{
The Institutional Approach to Economic History: \\ Connecting the Two Strands
}

Richard N. Langlois

University of Connecticut

Working Paper 2013-33

September 2013

365 Fairfield Way, Unit 1063

Storrs, CT 06269-1063

Phone: (860) 486-3022

Fax: (860) 486-4463

http://www.econ.uconn.edu/

This working paper is indexed on RePEc, http://repec.org 


\title{
The Institutional Approach to Economic History: Connecting the Two Strands
}

\author{
Richard N. Langlois \\ The University of Connecticut \\ Storrs, CT 06269-1063 USA \\ (860) 821-0152 (phone) \\ (860) 486-4463 (fax) \\ Richard.Langlois@UConn.edu
}

September 2013

FIRST DRAFT 


\begin{abstract}
This essay examines the historiography of two episodes in history - the scattering of plots in the open fields in the Middle Ages and the transition to the factory system in the Industrial Revolution - to shed light on the uses of institutional economics in economic history. In both of these episodes, economic "just-so" stories advanced our understanding of history. What animated intellectual innovation in both cases was a bold conjecture about the raison d'être of a puzzling institutional structure. But what ultimately enriched our understanding was the process of conjecture and revision those conjectures set off. In both episodes, the revised conjectures that best withstood criticism and revision were those that saw the phenomena not as static snapshots of economic agents confronting an economic problem but rather those that embedded the phenomena within a larger economic problem and within a process of economic change. In the end it is an account of institutional change - what I call the good old New Institutional Economics - that connects the use of institutional economics to explain puzzling historical phenomenon with the role of institutional economics in addressing the big questions of economic growth.
\end{abstract}

Journal of Economic Literature Classifications: B52, D02, D23, N01, N53, N63

Keywords: institutions, institutional change, transaction costs, open-field system, factory system. 
In recent years the economics of institutions has arguably taken center stage in economic history. ${ }^{1}$ What has been less well noted, however, is that economic historians have tended to practice their institutional economics in two seemingly quite different ways. Consider two recent books about institutions that the economic historian Maxine Berg (2012) saw fit to profile in the same brief review in the Times Literary Supplement: Why Nations Fail by Daron Acemoglu and James Robinson (2012) and The Institutional Revolution by Douglas Allen (2011). "These two books raise the same question," says Berg: "why are some countries so rich, and others so poor? The answer, according to both, lies in understanding not just capital, technology and property rights, but the institutions designed to maximize wealth and the costs of establishing and maintaining them" (Berg 2012, p. 28). Berg traces the institutional approach from Coase through figures like North, Greif, and Ostrom, and, in the case of Why Nations Fail, connects it to the larger literature on the "great divergence" in economic history (Diamond 1997; Landes 1998; Pomeranz 2001). Although terse, this characterization does trace the outlines of the institutional approach to economic history. In my view, however, Berg misses an important point in lumping these two books together as representative of the institutional approach. I would argue that these books represent two characteristic - but two very different - ways in which the economics of institutions has manifested itself in economic history.

1 As well as in its intellectual cousin, development economics. Once upon a time, the Third World was the whole world. 
Why Nations Fail is indeed a contribution to the debate about the great divergence: why are some nations so rich and others so poor? ${ }^{2}$ The Holy Grail - or maybe the MacGuffin - of this otherwise complex and nuanced debate is the predominant causal factor of economic growth. Why did the countries of northwestern Europe enjoy sustained intensive economic growth much earlier and to a much greater extent than other parts of the world? Was it because of geography and climate? Relative prices and factor abundances? Culture and ideas? Or, as economists from North to Acemoglu and Robinson have increasingly wondered, is it that northwestern Europe somehow adopted earlier than other regions certain kinds of institutions that proved conducive to sustained intensive economic growth $?^{3}$

But The Institutional Revolution is a different animal entirely. ${ }^{4}$ Despite the word "revolution" in its title, and despite the occasional weak nod in the direction of economic growth, this work is representative of a quite different, and arguably far more typical, application of the economics of institutions to economic history. In this version of the economics of institutions, which I will want to associate with the so-called New Institutional Economics (NIE) in its narrowest sense, one observes a (perhaps puzzling) matrix of institutions in history and asks: what problem were these institutions solving? Rather than labeling puzzling behaviors as ignorant and inefficient (as historians once tended to do) or exclusively as mechanisms for oppressing the lower classes (as many

To those authors Berg mentions I would add Allen (2009), Jones (2003), McCloskey (2010), and Mokyr (2002) as essential reading.

3 Geoffrey Hodgson (2006, p. 2) defines institutions as "systems of established and prevalent social rules that structure social interactions."

$4 \quad$ For an extended discussion of The Institutional Revolution, see Langlois (2013). 
still tend to do), the NIE attempts to explain such puzzles as responses to the costs, constraints, and scarcities the economic actors faced. This is the method of comparativeinstitutional analysis, inspired by Coase (1937, 1960), pioneered by Demsetz (1969), and championed by Williamson (1991). Rather than comparing actual (maybe puzzling) behavior against some imaginary frictionless standard, the NIE insists on comparing plausible institutional systems in real-world contexts rich in transaction (and other) costs. Explanation here consists in arguing that, and in detailing precisely how, the institutional system we observe is actually confronting some specified economic problem better than alternative candidates would have done. The hard part - the creative part - lies in discovering or imagining the right economic problem. What economic problem were they solving?

Some critics would immediately pounce on this characterization, seeing it not as the essence of good practice but as an example of all that is wrong with the NIE. By imagining alternative economic problems that observed institutions might be solving, these critics would say, one is creating a set of "just-so" stories: accounts that are sufficient but not necessary, that fit the facts but may not be the best, let alone the only, plausible story. The appropriate retort, I believe, is that good comparative-institutional analysis requires constant critical argument and analysis. One of the lessons of the philosophy of science, it seems to me, is that it is ultimately impossible to rule out theories on abstract methodological grounds. What defeats a weak theory in the end is another, stronger theory. Comparative-institutional analysis depends and thrives on criticism and revision. Without criticism and revision, the "which problem?" approach would indeed be a slightly less fanciful version of Kipling. But with criticism and 
revision, including criticism from empirical evidence of various kinds, the "which problem?" approach is essentially what evolutionary biologists do. ${ }^{5}$ I will mention below a couple of cases in which, I believe, the process of criticism and revision has refined, modified, and enriched institutional explanations that began (among economists) with a conjectured just-so story.

At the same time, I have long argued that it is important to place any just-so story in its proper temporal or historical context: to pay attention to how institutions change, not just to how they solve a static snapshot of an allocation problem (Langlois 1986). From a methodological point of view, one wants to engage institutional change because change helps focus us on the nature of the selection problem that inevitably sits behind every institutional problem. In asking the "which problem?" question, we really also need to ask: "why did this institutional solution come to be and why does it persist?" At the broadest level, of course, the answer to the existence and persistence question is ultimately some kind of mechanism of variation, selection, and retention (Hodgson and Knudsen 2010), even though conscious intention and design play a role in economic life that they do not have in Darwinian biology. At a finer level of detail, however, any explanation of specific institutional changes must take off from the initial conditions of some appropriate static "which problem?" conjecture. Institutional change in specific historical settings is about economic agents adapting to exogenous and endogenous changes in the economic problem they are confronting. Applying concepts like

5 Just one example: Ruxton (2002) surveys the various conjectures about, and evidence for, the benefits to zebras of having stripes. This is not an account of how the zebra got its stripes. As in the economics of institutions, the answer to the "how" question is evolution. But conjectures about the possible adaptive functions of stripes are an essential part of a specific account of the zebra. 
efficiency and optimality is no more appropriate here than it would be in assessing the "function" or adaptive properties of a relatively stable or static institutional system. But that doesn't mean that basic economic concepts like relative scarcities aren't essential to explaining the why and how of specific institutional changes. One goal of this paper is to argue in favor of one approach to bringing economic principles to bear on the phenomenon of institutional change - an approach I will call the good-old New Institutional Economics.

Notice also that an account of institutional change connects the two strands of institutionalism: it connects the "which problem?" question with the sources of economic growth. By identifying how the economic problems themselves change, we have some hope of talking about how resources might - sometimes - be channeled into increasingly more productive uses. That is to say, some hope of understanding the factors that are important for economic growth.

\section{Just-so stories: conjecture and revision, part 1.}

In the Middle Ages, European agriculture, and therefore the European economy, was dominated by a set of institutions called the open-field system. Although it was not fully ubiquitous, and although it had many subtle variants, this system characterized agricultural organization within a broad swath of the most productive land in Europe, beginning in recognizable form as early as the time of Charlemagne and lasting in vestiges until almost modern times. ${ }^{6}$ In the mature open-field system, villagers raised

6 The open-field system was not found in mountainous regions or where soil was unsuitable for farming. More interestingly, it tended not to be found in areas (like Kent near London, for example) 
grain in a system of three-course crop rotation on fields of several hundred acres each. At the same time, the villagers raised animals (often, but not exclusively, sheep), which grazed not only on common land but also on whichever fields lay fallow as part of the crop rotation. It is in this sense that the fields were "open": whereas individual villagers were entitled to the proceeds of specific parcels of land under cultivation, they lost those ownership rights under fallow in favor of communal grazing (Dahlman 1980; Hoffmann 1975; Thirsk 1964). Contrary to a widespread misconception, these common and open fields did not suffer a "tragedy of the commons." The resources were not unowned; they were collectively owned and managed through an evolved system of rules, of the sort famously studied by Elinor Ostrom (1990).

A puzzling feature of this system - indeed, one of the most intriguing institutional puzzles of European economic history - is that the holdings of the villagers were scattered. A single peasant would typically hold rights in all of the village's arable fields. Moreover, the peasant's holdings in any field were not a single continuous plot but took the form of narrow strips scattered all over the fields. Why? One answer might be that the phenomenon was an arbitrary arrangement; perhaps, as some historians implied, it was simply a holdover from an earlier time. But this interpretation is troubling at the very least, especially if, as many historians and even economists believed, scattering is a highly inefficient practice. Writing more than 100 years ago, for example, Frederic Seebohm denounced the practice in no uncertain terms. ${ }^{7}$

where farming was more specialized to supply urban markets (Dahlman 1980, p. 105 n. 12; Gray 1915, chapter 7). To this we will return.

$7 \quad$ Maitland (1897, p. 337) called scattering "this wasteful, cumbrous, barbarous plan." 
Now, judged from a modern point of view, it will readily be understood that the open field system, and especially its peculiarity of straggling or scattered ownership, regarded from a modern agricultural point of view, was absurdly uneconomical. The waste of time in getting about from one part of a farm to another; the uselessness of one owner attempting to clean his own land when it could be sown with thistles from the seed blown from the neighbouring strips of a less careful and thrifty owner; the quarrelling about headlands and rights of way, or paths made without right; the constant encroachments of unscrupulous or overbearing holders upon the balks - all this made the system so inconvenient, that Arthur Young, coming across it in France, could hardly keep his temper as he described with what perverse ingenuity it seemed to be contrived as though purposely to make agriculture as awkward and uneconomical as possible (Seebohm 1905, pp. 15-16).

Seebohm traced the practice of scattering to the heavy wheeled plow and the manner in which each peasant contributed oxen to the plow team. Yet scattering was common even in parts of Europe where the light plow was used. ${ }^{8}$ Perhaps the most common explanation was the Romantic one, from Vinogradoff (1892) through Homans (1941), that strips were scattered deliberately to maintain equality within the village in quantity and quality of land. Wrote the great Frederic Maitland: “And whence, we must ask, comes that system of intermixed 'strip-holding' that we find in our English fields? Who laid and the out those fields? The obvious answer is that they were laid out by men who would sacrifice economy and efficiency at the shrine of equality" (Maitland 1897, p. 337). This despite the empirical evidence that land was actually held among peasants in quite unequal proportions (McCloskey 1975b, p. 97). Another suggestion was partible inheritance: when land was continually subdivided in estates, it could end up in the form of small scattered holding (Thirsk 1964). A related argument involved the practice of assarting, that is, creating new arable out of the waste: those who cleared the new areas

For excellent critical surveys of what we may call these pre-cliometric accounts of scattering, see McCloskey (1975b) and Dahlman (1980, pp. 31-35), on which this paragraph draws. 
would be rewarded with the strips they cleared, which would result in holdings in in both old and new areas - and thus eventually all over the fields as assarting progressed (Bishop 1935). The argument from partible inheritance runs into the problem that scattering was more common in areas of England that practiced primogeniture than it was in areas that practiced partible inheritance. Beyond this, the argument from partible inheritance and the argument from assarting both suffer from the deficiency that they explain how scattering might have gotten started, but not why it persisted. If scattering was as costly and inefficient as Seebohm suggests, why didn't peasants exchange strips, in what were by all accounts well-functioning village land markets, in order to create compact holdings? (McCloskey 1975b).

The answer has to be that scattering was solving some economic problem for the villagers. The postulated technical inefficiencies of scattering were really just the cost side of an arrangement that was beneficial on net. Far from being irrational, scattering was economically efficient given the problem the villagers needed to solve. But what problem? It was here that McCloskey $(1972,1976)$ proposed a path-breaking just-so conjecture: scattering was in fact an efficient response to risk. Even over the small geographic reach of a manor's fields, soil condition are not uniform, and weather can change crop yields significantly. Villagers wanted to scatter their strips for the same reason that investors want to diversify their portfolios: don't put all your eggs in one basket. A peasant with a compact plot in only one area of the field could find that the weather has turned his land into a swamp and that his family faced starvation; despite its costs, scattering ensured that the peasant would possess at least some productive land in the field. 
Notice that McCloskey's hypothesis did not replace "real history" with a cliometric just-so story; it replaced earlier, and arguably flimsier, just-so stories - the plow, equality, partible inheritance, assarting. McCloskey brought economic reasoning to what was already an ongoing, if perhaps fitful, process of criticism and revision of just-so stories. And that process intensified.

McCloskey argued that peasants were rational (that is, acted in their economic interests) and employed markets far more than the nineteenth-century Romantic picture of the Middle Ages had led us to believe. But one market that peasants did not have available was the market for risk - an insurance market. Thus scattering. Led by Fenoaltea (1976), economic historians began assailing the proposition that peasants had no other mechanisms for dealing with risk. Grain storage is one possibility that remains theoretically and empirically controversial (Komlos and Landes 1991; McCloskey and Nash 1984). But on manorial villages, lords, who had little incentive to let their labor force die, likely provided a de facto safety net, as to some extent did the Church (Fenoaltea 1976, p. 133). More interestingly, Kimball (1988) suggested that villagers could have profitably set up their own mutual-insurance system, which he called a farmer's cooperative. Richardson (2005) found extensive archival evidence of such riskpooling cooperatives in medieval villages.

None of these criticisms means that scattering was not part of the peasant's system for dealing with risk. But such an array of alternative mechanisms does reduce the apparent value added of an arrangement that historians - including McCloskey - have viewed as fundamentally costly. 
Criticism is one half of the process; revision - proposing alternatives - is the other half. McCloskey's just-so story inspired other creative accounts of this mysterious institutional structure. Significantly, in my view, the most compelling of these confronted scattering not from the perspective of a snapshot of some problem medieval peasants faced but rather in light of the larger structure and historical evolution of the open-field system itself. Independently, Fenoaltea $(1976,1988)$ and Dahlman (1980) proposed different but related accounts in which the raison d'être of scattering lay in the essential role it played in the larger institutional system.

Early discussions of the open-field system tended to see the system as having always existed in its more-or-less fully developed form. In the 1960s, Joan Thirsk argued that the system had in fact evolved in pieces over time: common grazing on commons had existed from ancient times, but the more complex communal structures, including grazing on the fallow arable, scattering of strips, and collective management in a manor court or village meeting, developed later. This view fit in well with the developing theory of agrarian institutional change, argued by Ester Boserup (1965) and championed by Douglass North (North 1981; North and Thomas 1971), in which the Malthusian force of population pressure leads to institutional and technological response, of which the increasingly sophisticated structure of the open-field system was an example. We will consider the precise contours of a full theory of institutional change as we proceed; for the moment, the point is that explaining even a seemingly "static" and isolated feature of an institution may require understanding the complexity of that institution in a dynamic setting. 
In the Dark Ages after the fall of Rome (Ward-Perkins 2005), population declined precipitously in a world of violence and disorder. With the collapse of Roman law and authority, the disappearance of the Roman Legions, and the decay of Roman roads, communication, transaction, and transportation costs climbed. Lacking the necessary security and scale economies for cultivation of cereal crops, peasants retreated into what was essentially sedentary pastoralism (Hoffmann 1975). Eventually, the roving bandits of the era stumbled upon a way of grasping the $\$ 5$ bills that were lying on the ground: if instead of roving, the bandits settled down to protect (and extract rent from) a group of peasants, those peasants would be able to increase output, making the pie bigger ${ }^{9}$ (North and Thomas 1971). Thus the roving bandits became what Mancur Olson (1993) famously called sedentary bandits, the nobility of the medieval manorial system. Although these local warlords continued to dissipate rents on military activity throughout the medieval period, the system provided enough stability that population began to grow. ${ }^{10}$ On the demand side, this meant more mouths to feed; on the supply side, it meant more labor available; together it meant an increase in the cultivation of cereals relative to pastoralism, a development historians refer to as "de-stocking" (Hoffmann

9 Note here in passing that the just-so stories of the NIE are not - as is often alleged - always about efficiency. Another "problem" that institutions can "solve" is rent redistribution. A prominent example is the institution of serfdom. In the era when the roving bandits settled down to become sedentary bandits, farm labor was scarce relative to land. Thus labor not land should have earned the economic rents of the manorial arrangement. But by tying the workers to the land, the lords were implicitly using force to stop the labor market from working, thus preventing labor from bidding up its return (Domar 1970; North and Thomas 1971). (This is famously like the case of professional athletes in the U. S., who, before the end of the so-called reserve clause in the 1970s, were tied to their teams and could not sell their services on the free-agent market.) As population rose in the manorial era, the feudal services of serfdom tended to give way increasingly to rental and share-cropping arrangements, which is what this account would predict.

10 Because of the relative scarcity of farm labor in early feudal times, the feudal military substituted capital for labor - thus the capital-intensive cavalry of knights rather than large footsoldier armies. As a result, armies were small relative to population, and were more effective at defense than at territorial acquisition (Kohn 2005, chapter 19). 
1975; Thirsk 1964). Less for protection than because of the economies of cultivation with a growing population, peasants tended increasingly to abandon isolated small hamlets in favor of villages; and they began to cultivate larger fields collectively, with what evolved into the organization institutions of the open-field system: the ancient practice of common grazing now managed in a sophisticated way at the village level, then eventually crop-rotation, grazing on the fallow (called common of shack), and a variety of other rules and practices (Hoffmann 1975) - all very much the sorts of rules and practices Ostrom (1990) has described in other contexts. And, of course, scattering.

Significantly, however, this increase in population, and this increased sophistication and collectivization of subsistence farming, was taking place in what was still a world of high transaction and transportation costs. In the large, the open-field system was very much a response to the problem of subsistence farming in a world in which inter-village trade in grain was prohibitive: it was a solution to what was essentially the problem of autarkic village production (Dahlman 1980). This problem was made more complex by the interrelationship between animal husbandry and grain cultivation: animals needed fodder, but also produced valuable fertilizer. In other times and places, this problem of interdependency would be solved by specialization and the use of fodder crops. But given the state of technological knowledge, population levels, and (especially) the high costs of transacting across villages, the open-field system - far from being an ignorant and barbarous system - was an elegant solution to the problem people of the time faced. The complex Ostromian rules of the system effectively partitioned tasks in a way that minimized both production costs and monitoring costs. Tasks with a high minimum efficient scale but low monitoring costs (like plowing or 
harvesting) were undertaken collectively; tasks with low MES and high monitoring costs (like the cultivation by hand of distant parts of the field) were governed by a system of property rights, making the peasants self-monitoring residual claimants (Dahlman 1980; Fenoaltea 1976, 1988).

What has all this to do with scattering? In the accounts of both Dahlman and Fenoaltea, scattering appears because it is essential to the functioning of the complex set of rules governing the open-field system.

As a graduate student at UCLA in the late 1970s, Dahlman was heavily influenced by the emerging theory of asset-specificity and hold-up that has since come to exert considerable - one might even say excessive - force on the economics of organization (Klein, Crawford and Alchian 1978). For Dahlman, scattering was a way of avoiding the problem of hold-up. He lays great stress on the benefits of economies of scale in grazing. If a peasant were to accumulate a large enough bundle of contiguous land, that peasant could threaten to withdraw from the grazing collective, thus reducing scale and harming the remaining villagers. Quite apart from the question of precisely what and how the peasant would gain if the threat were successful, this explanation falls up against the problem that such a threat is not credible: the very assumption of scale economies in grazing means that the threatening peasant hurts himself more than he hurts the collective. Moreover, there were more effective methods of preventing hold-up (Fenoaltea 1988). (Certainly the many lords whose villages employed scattering would have had something to say about the matter.) 
The legal theorist Henry Smith has more recently singled out a different strategic possibility as the raison d'être of scattering (Smith 2000). The essence of the open filed system, he says, was not a commons; rather, the system is an archetypal example of a mixed-ownership regime, a semicommons. "In a semicommons, a resource is owned and used in common for one major purpose, but, with respect to some other major purpose, individual economic units — individuals, families, or firms - have property rights to separate pieces of the commons" (Smith 2000, p. 131). This generates strategic possibilities. A clever private owner could try to manipulate the common aspects of production in a way that benefits his private ownership. Smith has in mind a rather specific strategic arena: the common grazing of sheep. To control grazing on the fallow, villagers would use a portable fence called a sheepfold, which could direct the sheep onto specific pieces of land. A peasant taking a turn as shepherd could arrange the sheepfold so as to deposit more manure on his own land and to ensure that the sheep trampled other people's land. ${ }^{11}$ Scattering provides a way to mitigate this kind of strategic behavior by making it harder to identify and single out individual land and thus harder to manipulate the foldcourse. In fact, however, the foldcourse system was not coextensive with scattering, and often the foldcourse was controlled not by the peasants but by a lord, whose land lay in a demesne separate from the fields, and who would in any case have had no incentive to favor certain peasants over others (Bailey 1990). Of course, peasants might scatter to protect themselves from general unpredictability in the use of the sheepfold. But this is a quite a different explanation, to which we will now turn.

11 Trampling of the fields - which compacted the soil and made later cultivation more difficult - is an effect on which Smith hangs much of his tale, but it is an effect for whose importance he supplies surprisingly little evidence. In fact, however, the foldcourse was important even in areas like the Brecklands, where the sandy soil would have made trampling an irrelevant concern (Bailey 1990). 
It is possible, I argue, to read Dahlman's account in a slightly different and more capacious way. In this wider view, scattering operates not merely to protect collective grazing against strategic peasants but more significantly to protect the entire ensemble of adapted rules. The fulcrum of the open-field system is not economies of scale in grazing but rather the sophisticated way in which the system manages an array of interrelated tasks with differing monitoring-cost properties and different minimum efficient scales. The open-field system was a set of rules à la Ostrom to manage a complex semicommons, adapted to the problem of autarkic subsistence agriculture given highmedieval relative scarcities of labor and land. In this reading, scattering does more than prevent hold-up; it creates incentives that reinforce rather than destroy that finely tuned system of collective management.

Many present-day economic historians agree with Seebohm (in the quote earlier) that the costs of scattering were not mostly the costs of travel to the scattered strips but rather the externalities that adjacent strip-holders could easily inflict on one another: neighborhood effects (McCloskey 1975b, p. 80). The carelessness or deliberate malfeasance of one peasant - with respect to drainage or weeds, for example - could easily affect the output of the others whose land was interwoven with his own, creating general incentives for lower effort and implying lower output in the aggregate. Thus even if scattering avoids costs of strategic behavior, it imposes other costs. As Dahlman (1980, p. 127) suggests, however, neighborhood effects are precisely the sorts of problems the system of communal rules and procedures is best able to handle. Moreover, neighborhood effects are almost certainly less costly to address and adjudicate in the context of a manorial court or village meeting than in any larger judicial setting (or in 
setting of no adjudication at all). By creating problems best solved with the apparatus of the open-field system, then, the costs of scattering "serve to increase the incentive to participate in the communal organization" (Dahlman 1980, p. 126).

“Generally," writes Smith (2000, p. 131), "boundary placement and norms are substitute methods of addressing strategic behavior in a semicommons." In both Smith's story and the narrow version of Dahlman's, scattering represents a form of boundary placement necessary to overcome strategic behavior that norms (or other collective rule mechanisms) can't handle. But in the wider story I'm advocating, boundary placement and norms may be complementary. ${ }^{12}$

This becomes even clearer in Stefano Fenoaltea's (1976, 1988) account of scattering, which may be the most sophisticated of the cliometric just-so conjectures. Like Dahlman, Fenoaltea holds that scattering makes sense only in the context of the open-field system as a whole. What would be the alternative to a collective management system? Unified ownership of the entire farm in fee simple, a clear solution by boundary placement. ${ }^{13}$ In such a system, an owner would employ workers at a wage and direct them in which tasks to undertake. Compared with a residual-claim system, this has bad incentive properties, because workers will now want to shirk. But such an arrangement essentially the Coasean firm (Coase 1937) - has an advantage if there are offsetting benefits to central direction. Fenoaltea's insight is that central direction would still have had value in open-field farming. As in the Coasean firm, the benefits of central control

12 Another way to say the same thing, of course, would be that scattering is not a form of boundary placement at all but rather an attempt to blur the placement of boundaries while at the same time retaining the power of residual-claimant incentives.

13 This is an oversimplification, of course, as a number of hybrid systems are possible. 
come from flexible adaptation in a world of uncertainty (Langlois 2007, pp. 1110-1111). Suppose that on a certain day, given the weather and time of year, the northwest corner of Field A desperately needs attention, but other parts of other fields can wait. A central farm manager could order all the workers to attend to the northwest corner of Field A. The village council could make a similar request; but in a residual-claim system in which villagers held distant compact plots, no one would have an incentive (even that of a paycheck) to go off and work on someone else's field, especially if the situation were not an emergency but simply part of the day-to-day flow of exigency in farming. With scattering, however, each peasant holds land in every part of every field (or near enough), so that every peasant has an incentive to allocate his labor in the collective interest. By making each peasant's holdings mimic (at least to some extent) the fields as a whole, scattering enables some of the flexibility benefits of central direction without destroying the incentive benefits of the residual claim.

Fenoaltea lays great stress on the labor-allocation benefits of scattering. But here too there are additional benefits. We might say that whereas Smith sees scattering as protecting peasants from one another, and Dahlman sees scattering as protecting the collective from the peasants, Fenoaltea sees scattering as protecting the peasants from the collective. If the lord's sheepfold neglects the northwest corner of Field A, or if in a bounty year the harvest team never reaches that corner, the peasant has other, luckier, strips to fall back on. In this respect, we have circled back to McCloskey, who saw scattering as protecting the peasant against nature (only). In this larger story, however, scattering provides flexibility and diversification against a variety of contingencies, many 
of which are not exogenous but are essential elements of the collective management system of the open fields.

Recall that, in the Boserup-North theory, population growth is a key driver of institutional change in agriculture. The collectivization of mixed grain-and-animal subsistence farming - the open-field system - was a successful adaptation to the conditions of the High Middle Ages. As Malthus teaches, however, in a pre-modern economy, no economic success goes unpunished. The advantages of the open-field system led to population growth, which began to alter the relative prices (and other underlying factors) to which the system had been adapted. Europe's first response to this population growth was along the extensive margin: a "frontier movement" (North and Thomas 1971, p. 783) in which the open-field system was rubber-stamped upon the relatively less populated lands of eastern Europe. When cheap land became exhausted, however, Europe turned to the intensive margin. Because of the complex rule-based structure of the open-field system, with its many stakeholders and its many institutional complementarities, diminishing returns began to set in rapidly. Villages increased the arable by assarting, but by the fourteenth century the real wage began to fall below subsistence, and a Malthusian crisis set in, of which the Black Death - exogenous but exacerbated by famine and crowding - was but one horseman (North and Thomas 1971, p. 798).

What had been needed was a new adaptation. Given higher levels of population and lower transportation and communications costs in Europe, the appropriate adaptation would have been to abandon a system designed for autarkic village production and to 
specialize and trade instead. Although the open-field system was a semicommons by Smith's definition, it nonetheless offered the resistance to change typical of an anticommons, in which many holders of potential vetoes must be persuaded simultaneously ${ }^{14}$ (Buchanan and Yoon 2000). The death by plague of a third of the population cut the Gordian knot, altering relative prices so dramatically as to radically disrupt property relations (Haddock and Kiesling 2002). One manifestation of this was the enclosure movement, in which the complex property rights of the open-fields were unbundled in favor of tenancy in fee simple (Dahlman 1980; McCloskey 1975a). There is considerable debate about the immediate gains in efficiency from enclosure, but little disagreement about the long-term benefits it generated in terms of increased trade and, especially, technological and organizational innovation (Fenoaltea 1988).

\section{Just-so stories: conjecture and revision, part 2.}

In England, enclosure came in two waves: the first, early on, for specialization in sheep raising; the second, well into the early-modern period, for reasons associated with new agricultural techniques. ${ }^{15}$ In their "Marxian" explanation of enclosure, Cohen and Weitzman (1975) make a point that is actually quite consistent with North's story. Because the open-field system was a village system, it employed all members of the village, even if that meant that the amount of labor was beyond the point that would have been profit maximizing for a specialized farm - North's diminishing returns in another guise. The Marxian part of this is presumably that the workers freed up by enclosures

14 "The costs of changing from one system of agriculture to another must figure prominently in an account of the enclosure movement" (McCloskey 1972, p. 20).

15 According to Wordie (1983), 45 per cent of common land was enclosed prior to 1550 - the so called Tudor enclosures. Enclosure slowed until the 17th century, when a further quarter of the original common land was enclosed. 
would have been made worse off in the near term, even though, as Cohen and Weitzman acknowledge, the freed-up labor of the early enclosures, combined with Britain's specialization in sheep farming, ultimately coevolved into a dynamic woolen industry.

Capitalists - merchant clothiers, as they were called - realized that they could turn underemployed rural labor to advantage, and at the same time evade the regulations of the urban cloth guilds, by putting out spinning and weaving to the countryside. The cottagers were genuinely contractors not workers; they owned their own machinery and received compensation by the piece. This was an effective incentive system, since spinning and weaving by hand in the countryside had low economies of scale and high monitoring costs. By the late eighteenth century, however, the putting-out system - in cotton by this time - came to be challenged by the so-called factory system, in which operatives relocated to a central factory, worked with machines they did not own, and received a wage instead of a piece rate. As Dahlman (1980, pp. 209-210) has pointed out, a juxtaposition of the enclosure movement and the factory system presents a seeming paradox. In the case of enclosure, efficiency dictated a movement from collective management to individual private ownership (of land), whereas the transition to the factory system implied the reverse, a movement from individual private ownership to collective ownership (of capital equipment). ${ }^{16}$

This is not a paradox, of course, since robust and durable organizational forms exist to solve some economic problem. Why give up the self-monitoring benefits of

16 Until far into the end of the nineteenth century, of course, the pooling of capital ownership, if any, was limited to partnerships, whose members tended to be few enough that monitoring costs were not high and incentives to monitor were strong. 
putting out in favor of a wage system with higher monitoring costs? The traditional account among economic historians had always been machinery: the factory system emerges upon the invention of large-scale high-throughput textile machinery ${ }^{17}$ (Landes 1986; Mantoux 1961; Ure 1861).

I will argue that, in this case, the traditional conjecture of the historians was in fact well founded, albeit incomplete along a crucial dimension. Nonetheless, here too a novel just-so conjecture stirred the intellectual pot. In his famous radical broadside, Stephen Marglin (1974) announced that one could understand the transition to the factory system as a purely organization matter - not a matter of technology. Holding technology constant, he argued, bosses want to switch to the factory system because it enables them to break work into simple tasks and thus to "deskill" the workers, which shifts the rents of skill away from laborers and onto capitalists. ${ }^{18}$ Institutional economists responded to Marglin as both threat and opportunity: Marglin was wrong about exploitation, but right that one could explain the factory system by looking only at transaction costs. Williamson (1980) constructed a thought experiment in which, holding technology constant, the putting-out system appears more costly than the factory system, largely because outsourcing permitted greater "embezzlement," as pilfering of materials was called, and required larger work-in-process inventories.

The claim that transaction costs alone explain the factory system was a just-so conjecture that began a thorough and fruitful reexamination of the origins of the factory system. Economic historians jumped in to point out that, in history as it actually

17 "The factory system ... was the necessary outcome of the use of machinery" (Mantoux 1961, p. 246).

18 Compare the discussion of serfdom above. 
happened, technology did not remain constant, and in fact it was production costs not transaction costs that drove this institutional change. In the era of hand-operated machines, production costs for the putting out system were lower by a third than for a system requiring workers to congregate in one place (Jones 1982, 1999). This was so because, among other reasons, cottagers continued to engage in agriculture, producing food from their own crofts and earning occasional income from farm labor, all of which lowered the opportunity costs of textile work. Moreover, although embezzlement did take place and cottagers had to hold inventories while waiting for their output to be collected, economic historians tend to argue that those costs were relatively low (Clark 1994; Jones 1982), especially in view of the favorable monitoring-cost properties of what was essentially a self-monitoring residual-claim system.

Writers like Szostak (1989) and Allen (Allen 2011) have continued to push for a pure transaction-costs explanation: "the advantages the factory possessed were almost entirely in terms of the opportunity provided for supervision of workers" (Szostak 1989, p. 344). With decreased transportation costs, they argue, trade was becoming increasingly anonymous, and embezzlement and lack of standardization were becoming more costly. Changing technology cannot explain the transition, they claim, because many centralized workplaces emerged in this period using exactly the same technology as the cottagers. What reason could there be for this centralization other than the desire to monitor for embezzlement, product quality, and standardization?

Once again, the answer appears if we look at the dynamics of the system rather than at contested snapshots. It is certainly true that, as transportation costs fell and markets expanded, it began to pay to tap labor outside of the pool of cottagers, especially 
labor within the developing urban areas, where earlier guild regulation had largely fallen by the wayside. But - notably in textiles - this was simply because the extent of the market was growing at a rate that was beginning to outstrip the capacity of the puttingout system. Capitalists turned to urban workshops to meet the demand. If capitalists had switched away from putting out to centralized workshops largely to reduce embezzlement, we should expect to see decline, or at least stagnation, in the putting-out system. Instead, what we see before mechanization is a growth both in urban workshops and in the putting-out system (Jones 1999, p. 40), as the expansion of the market for British textiles drove the putting-out system beyond the point of diminishing marginal returns. The result was technological and institutional change. Urban workshops were the beginning of that change; mechanization and the full-fledged factory system were a

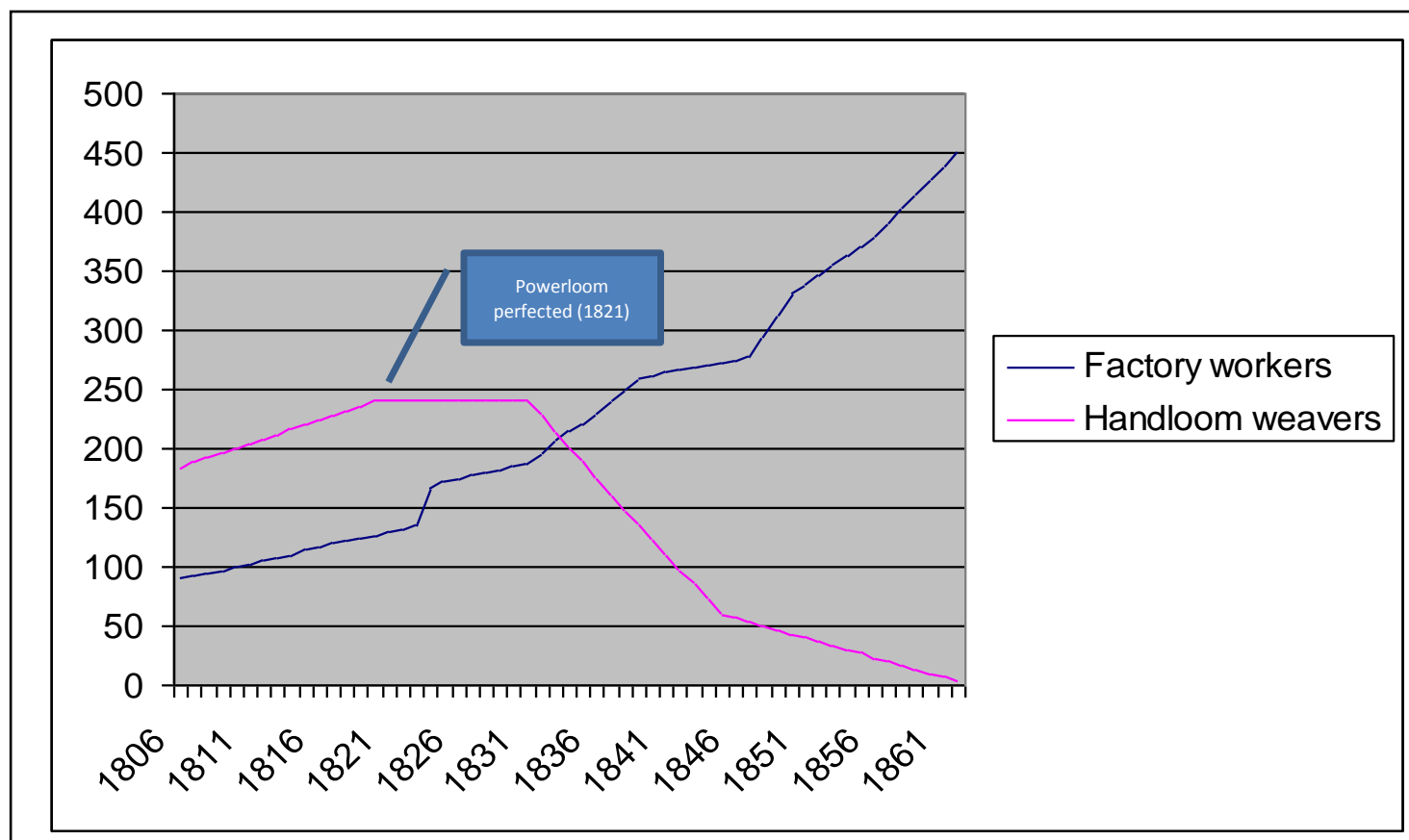

Factory workers and handloom weavers in Britain, 1806-1862 (in thousands).

Source: Mitchell (1988, p. 376) 
more significant response. Only with the advent of mechanization did the putting-out system begin to decline. ${ }^{19}$ (See Figure.)

Operatives in workshops using the technology of the cottagers were paid like the cottagers — by the piece — making them essentially inside contractors (Buttrick 1952). When human power gave way to inanimate power, however, the operatives tending the machines were increasingly confronted with a wage rather than a piece-rate contract. ${ }^{20}$ Why should this be? Retaining the piece-rate system - converting outside contracting into inside contracting - would have retained the monitoring-cost benefits of a residualclaim system without impeding supervision for quality control and against embezzlement. Why switch to a system of hourly wages, which is canonically notorious for problems of moral hazard? This is a question the traditional historian's analysis had never confronted.

High-throughput machinery was an innovation induced in response to the encroaching limits of the putting-out system and of the piece-rate system more generally. As the economic historians tell us, the coming of inanimate power eliminated the worker's comparative advantage in owning capital (Landes 1986). Whereas to the textile capitalist the putting-out system had been a low-fixed-cost high-variable-cost system, powered machinery came with high fixed costs, and it meant that the capitalist not the worker would pay those fixed costs. So factory owners were extremely anxious to keep

19 Note that Marglin's story has even bigger problems than the embezzlement story, as he cannot explain the timing of the factory system at all. If it was just about organization, why did earlier capitalists not pick up all the supposed $\$ 5$ bills of deskilling? Why did they wait until there were machines?

20 Some piece rates continued even in a factory setting, as in the case of master spinners, who were effectively inside contractors who did not own their own machines (Lazonick 1990, pp. 80-85). But these master spinners were themselves employers (indeed the principal employers of child labor in the period) and they did not pay their own employees by the piece. 
the machinery constantly operating in order to spread their costs over as many units of output as possible. Because the supply curve of worker effort was backward-bending at contemporary income levels, the capitalists could not ensure high throughput simply by manipulating the piece rate. What was called for was a non-marginal institutional change: a switch to a system in which capitalist and worker could somehow strike a highpay high-effort wage bargain ${ }^{21}$ (Clark 1994; Lazonick 1990). To enforce the bargain and counteract shirking, the capitalists had to hire supervisors to apply factory discipline, which was far more about keeping up effort levels than it was about ferreting out embezzlement (Pollard 1963).

\section{Institutional change.}

In both of these episodes, economic just-so stories advanced our understanding of history. What animated intellectual innovation in both cases was a bold conjecture about the raison d'être of a puzzling institutional structure. But what ultimately enriched our understanding was the process of conjecture and revision those conjectures set off. In both episodes, the revised conjectures that best withstood criticism and revision were those that saw the phenomenon not as a static snapshot of economic agents confronting an economic problem but rather those that embedded the phenomenon within a larger economic problem and within a process of economic change.

21 For a fuller analysis of this argument, and of the historiography of the transition to the factory system more generally, see Langlois (1999). 
My version of the historiography of these two episodes falls squarely within the explanatory focus of what I want to call the good old New Institutional Economics. ${ }^{22}$ By this I mean an approach, going back at least to the early North, in which economic variables take center stage in explaining institutions and institutional change. Gary Libecap (1989, p. 16), one of the outstanding practitioners of this approach, offers a short list of the factors that influence institutional change:

1. Shifts in relative prices.

2. Changes in production and enforcement technology

3. Shifts in preferences and other political parameters.

Shifts in relative scarcities drove explanation in both the open-field case and the factory system case. In general, I see such shifts in terms of growth in the extent of the market. In the Middle Ages, when inter-village transportation and transaction costs were high, population and extent of the market were essentially the same thing, and population pressure (which changed the relative scarcity of labor) led to the formation of the openfield system as well as to its demise. During the Industrial Revolution, increasing extent of the market for cotton textiles pulled the putting-out system beyond the point of diminishing returns. In neither case was an exogenous change in production technology important. In the case of the factory system, the change in production technology was part of the explanandum.

22 This is obviously adapted from McCloskey's (1997) idea of the "good old Chicago School." Indeed, the good old New Institutional Economics is arguably a wing of or outgrowth of that School. 
In the case of the open-field system, changes in the technology of enforcement (or transaction costs more broadly) mattered (only) in the sense that transportation and communications costs were declining on average throughout the medieval period, which made specialization more attractive than autarkic production. In the case of the factory system, enforcement costs figured heavily in the explanation, even as I rejected explanations that hinged exclusively on changes in enforcement costs. ${ }^{23}$ Nonetheless, economic history is full of examples in which changes in the costs of enforcement are central. As example might be Greif's (2002) account of the evolution of institutions governing contract enforcement in long-distance trade. In the High Middle Ages, as we saw, the extent of the market for long-distance trade was restricted by high transportation and transaction costs. One of the main sources of transaction costs was the absence of effective institutions of contract enforcement. As a result, trade often took place within ethnic networks (Landa 1994). As transportation costs declined in the later Middle Ages and commercial city states began to thrive in places like Italy and the low countries, trade became increasingly the province of merchants who, although members of a local merchant guild, were anonymous on the larger European stage. How could these merchants expect their long-distance trading partners to honors their contracts? Greif's answer is that a new mechanism of enforcement emerged, the Community Responsibility System. If Giovanni from Genoa reneges on his promise to Ambrose in Amsterdam, the Dutch cannot easily find the culprit let alone sanction him appropriately. But the relevant

23 It is my principal complaint about Allen (2011) that his entire story hinges on changes in enforcement costs. In fact, we need to argue about which alternative institutional structure minimizes the sum of production costs and transaction costs, and we have to recognize that there can be tradeoffs between the two (North 2005, p. $15 \mathrm{n} 3$; Williamson 1985, p. 22). In many cases, a reduction in production costs leads to (although more than offsets) an increase in transaction costs. The factory system case is an example. 
merchant guild of Amsterdam could boycott all trade with Genoa. Punishing the innocent along with the guilty (Miceli and Segerson 2007) creates an incentive for the Genoese themselves to find Giovanni and sanction him.

Notice, however, that here too growth in the extent of the market was a crucial part of the explanation of how institutions changed. It was growth in the extent of the market that increased the transaction costs that made unworkable smaller-scale enforcement systems like ethnic networks. ${ }^{24}$ Indeed, as trade volume increased further in the early modern period - in part as a result of the success of the Community Responsibility System - even the local guilds found it difficult to identify and sanction those who reneged on contracts. Eventually states took over the role of enforcing contract law, imposing sanctions at the level of the individual. Greif calls this the Individual Responsibility System. Notice that in all these stories, institutions often contain the seeds of their own destruction (North 1981, 1990): their very success in solving the economic problem with which they were confronted increases the extent of the market, alters relative prices and transaction costs, and eventually creates a new economic problem to which the original institution is no longer adapted. ${ }^{25}$

Shifts in preferences and political parameters did not figure heavily in our two main cases. But there is no reason in principle why such effects cannot be as important in economic history as they are in examples nearer to the present day. In Libecap, and more

\footnotetext{
24 And also trade fairs like the famous ones in Champagne (Milgrom, North and Weingast 1990).

25 Greif (2006, p. 159), who likes to answer the "what problem were they solving?" question with game theory, distinguishes between variables and quasi-parameters. In effect, variables adjust to solve the "problem" posed by a given set of parameters; change in the (quasi) parameters leads to a new problem, and thus to a new solution - that is, to institutional change. Presumably institutional change can be endogenous to the extent that changes in the variables can effect changes in the parameters.
} 
explicitly in the related formulation of Ruttan and Hayami (1984), institutional change depends on both a demand side and a supply side. The demand side is all the $\$ 5$ bills lying on the ground. Exogenous or endogenous changes in relative prices, technologies, or other economic parameters create rents that entrepreneurial agents can seize if they are able to alter the institutional matrix (Demsetz 1967). The supply side is the costs of changing those institutions, which in modern contexts may be most often Public Choice costs. Consider long-distance telephony, where an exogenous technical change microwave transmission - created opportunities for whoever could open up AT\&T's legal hold on the field. ${ }^{26}$ Entrepreneur William McGowan of MCI poured resources first into persuading the Federal Communications Commission to alter its policies and then into fomenting the breakup of AT\&T (Temin and Galambos 1987). The costs McGowan incurred were a function of the political parameters of the U. S. political system after World War II.

In our earlier historical examples, the costs of institutional change had more to do with the structure of the institutions themselves. Importantly, institutional structures can have varying degrees of modularity (Langlois 2002). As I intimated by using the term anticommons, the ownership structure of the open-field system was very much a nonmodular system. Because of the complex complementarities among rules, there was no gradual path, and change was discontinuous, not to say catastrophic. In the case of the factory system, ownership, as we saw, was already modular, and the new structure of technology and ownership could supplant the old in a much more piecemeal, if not in the

26 In this case, the possibilities arose in part because of AT\&T's pricing structure, which for political reasons had subsidized local service at the expense of long distance - a misalignment with relative scarcities made possible by AT\&T's status as a regulated monopoly (Vietor 1994, p. 183). 
end less rapid, way. It is, I think, a general point that Ostrom-style systems of rules, which work well in small face-to-face societies, are typically non-modular and do not have the flexibility of what Smith calls systems of boundary placement. That does not mean that non-modular institutional systems can never evolve gradually. Mahoney and Thelen (2010) point out that new rules can be added on top of old rules, and old rules can change their meaning and function. Nonetheless, change in both of our historical cases took place in the main by what Mahoney and Thelen would call displacement - the old rules disappeared and new systems of rules took their place. $^{27}$

Have we now connected the two strands of the New Institutional Economics in economic history? With reservations, the answer is yes. The right question is not only "what problem were they solving?" but also "how did that problem emerge and how did it, and its institutional solution, change over time?" At some level, a theory of institutional change is a theory of economic growth. Both are about the process of discovering and seizing $\$ 5$ bills. This is not to say, of course, that all rent-seeking, or all institutional change, is productive. In explaining the great divergence, after all, one has to explain not only why Western Europe was successful but also why so many other places were not and indeed still are not successful (North 1990).

McCloskey (2010) raises the objection that, although a theory of institutional change can explain transformations like enclosure and the factory system that enhanced

27 This may be in part a function of the wide-angle lens typical of the historiography, as against the detailed history, of the open fields. For example, by the early modern period in the Brecklands, manorial lords had become capitalist flockmasters specialized in sheep farming and possessed of large herds; but the lords continued to fold sheep on the fallow lands of peasants, who had almost entirely ceased to own sheep themselves in favor of cereals production (Bailey 1990). A close examination of this transformation would no doubt detect examples of the processes Mahoney and Thelen (2010) call institutional layering, drift, and conversion. 
productivity and raised income per capita, it cannot explain what McCloskey rightly sees the central explanandum of economic history and one of the most remarkable facts of human history - the absolutely spectacular quantitative rise in real incomes per capita, of at least a factor of 30 (and probably more if corrected properly for changes in quality as well as quantity of goods and services consumed), over the last two centuries or so in the West. I interpret this objection in the following way. It may well be possible that some institutional change - perhaps secure property rights and relative economic freedom (North 1981); perhaps the institutions of post-Enlightenment science and inquiry (Mokyr 2002); perhaps a change in attitudes towards commerce and the bourgeoisie (McCloskey 2010); perhaps something else - once in place enabled rapid change in the economic variables of growth without the underlying institution itself continuing to change. Incomes went up, but property rights didn't get more secure and science or commerce didn't get more fashionable. This may well be true at the level of macro institutions. But what underlay that remarkable rise in incomes was surely a continual process of seizing $\$ 5$ bills at some level. Within the framework of these larger institutional structures, the process of institutional change continued at various meso and micro levels as entrepreneurs discovered new organizational and forms and new institutional systems. 


\section{References.}

Acemoglu, Daron and James A. Robinson. 2012. Why Nations Fail: The Origins of Power, Prosperity, and Poverty. New York: Random House.

Allen, Douglas W. 2011. The Institutional Revolution. Chicago: University of Chicago Press.

Allen, Robert C. 2009. The British Industrial Revolution in Global Perspective. Cambridge: Cambridge University Press.

Bailey, Mark. 1990. "Sand into Gold: The Evolution of the Foldcourse System in West Suffolk, 1200-1600," Agricultural History Review 38(1): 40-57.

Berg, Maxine. 2012. Sink or Swim. The Times Literary Supplement. London: 28.

Bishop, T. A. M. 1935. "Assarting and the Growth of the Open Fields," The Economic History Review 6(1): 13-29.

Boserup, Ester. 1965. The Conditions of Agricultural Growth: The Economics of Agrarian Change under Population Pressure. Chicago: Aldine.

Buchanan, James M. and Yong J. Yoon. 2000. "Symmetric Tragedies: Commons and Anticommons," Journal of Law and Economics 43(1): $1-13$.

Buttrick, John. 1952. "The inside Contract System," The Journal of Economic History 12(3): 205-221.

Clark, Gregory. 1994. "Factory Discipline," The Journal of Economic History 54(1): 128-163.

Coase, Ronald H. 1937. "The Nature of the Firm," Economica (N.S.) 4: 386405. 
Coase, Ronald H. 1960. "The Problem of Social Cost," Journal of Law and Economics 3: 1-44.

Cohen, Jon S. and Martin L. Weitzman. 1975. "Enclosure and Depopulation: A Marxian Analysis," in William N. Parker and Eric L. Jones, eds., European Peasants and Their Markets. Princeton: Princeton University Press, pp. 161-176.

Dahlman, Carl J. 1980. The Open Field System and Beyond. New York: Cambridge University Press.

Demsetz, Harold. 1967. "Toward a Theory of Property Rights," The American Economic Review 57(2): 347-359.

Demsetz, Harold. 1969. "Information and Efficiency: Another Viewpoint," Journal of Law and Economics 12(1): 1-22.

Diamond, Jared. 1997. Guns, Germs, and Steel: The Fates of Human Societies. New York: W. W. Norton.

Domar, Evsey D. 1970. "The Causes of Slavery or Serfdom: A Hypothesis," The Journal of Economic History 30(1): 18-32.

Fenoaltea, Stefano. 1976. "Risk, Transaction Costs, and the Organization of Medieval Agriculture," Explorations in Economic History 13: 129151.

Fenoaltea, Stefano. 1988. "Transaction Costs, Whig History, and the Common Fields," Politics \& Society 16(2-3): 171-240 (June).

Gray, Howard Levi. 1915. English Field Systems. Cambridge: Harvard University Press.

Greif, Avner. 2002. "Institutions and Impersonal Exchange: From Communal to Individual Responsibility," Journal of Institutional and Theoretical Economics 158: 168-204. 
Greif, Avner. 2006. Institutions and the Path to the Modern Economy: Lessons from Medieval Trade. New York: Cambridge University Press.

Haddock, David D. and Lynne Kiesling. 2002. "The Black Death and Property Rights," The Journal of Legal Studies 31(S2): S545-S587.

Hodgson, Geoffrey M. 2006. "What Are Institutions?," Journal of Economic Issues 40(1): 1-25.

Hodgson, Geoffrey M. and Thorbjørn Knudsen. 2010. Darwin's Conjecture: The Search for General Principles of Social and Economic Evolution. Chicago: University of Chicago Press.

Hoffmann, Richard C. 1975. "Medieval Origins of the Common Fields," in William N. Parker and Eric L. Jones, eds., European Peasants and Their Markets. Princeton: Princeton University Press.

Homans, George. 1941. English Villagers of the Thirteenth Century. Cambridge: Harvard University Press.

Jones, Eric L. 2003. The European Miracle: Environments, Economies and Geopolitics in the History of Europe and Asia. Cambridge: Cambridge University Press.

Jones, S. R. H. 1982. "The Organization of Work," Journal of Economic Behavior and Organization 3(2): 117-137.

Jones, S. R. H. 1999. "The Origins of the Factory System in Great Britain: Technology, Transaction Costs, or Exploitation?," in Paul L. Robertson, ed., Authority and Control in Modern Industry. London: Routledge, pp. 17-44.

Kimball, Miles S. 1988. "Farmers' Cooperatives as Behavior toward Risk," The American Economic Review 78(1): 224-232.

Klein, Benjamin, Robert G. Crawford and Armen A. Alchian. 1978. "Vertical Integration, Appropriable Rents, and the Competitive Contracting Process," Journal of Law and Economics 21(2): 297-326. 
Kohn, Meir. 2005. The Origins of Western Economic Success: Commerce, Finance, and Government in Pre-Industrial Europe. Hanover: Dartmouth College, Unpublished Manuscript. Available at: http://www.dartmouth.edu/ mkohn/.

Komlos, John and Richard Landes. 1991. "Anachronistic Economics: Grain Storage in Medieval England," The Economic History Review 44(1): $36-45$.

Landa, Janet T. 1994. Trust, Ethnicity, and Identity: The New Institutional Economics of Ethnic Trading Networks, Contract Law, and GiftExchange. Ann Arbor: University of Michigan Press.

Landes, David S. 1986. "What Do Bosses Really Do?," The Journal of Economic History 46(3): 585-623.

Landes, David S. 1998. The Wealth and Poverty of Nations: Why Some Are So Rich and Some So Poor. New York: W. W. Norton.

Langlois, Richard N. 1986. "Rationality, Institutions, and Explanation," in Richard N. Langlois, ed., Economics as a Process: Essays in the New Institutional Economics. New York: Cambridge University Press, pp. 225-55.

Langlois, Richard N. 1999. "The Coevolution of Technology and Organization in the Transition to the Factory System," in Paul L. Robertson, ed., Authority and Control in Modern Industry. London: Routledge, pp. 45-72.

Langlois, Richard N. 2002. "Modularity in Technology and Organization," Journal of Economic Behavior \& Organization 49(1): 19-37 (Sep).

Langlois, Richard N. 2007. "The Entrepreneurial Theory of the Firm and the Theory of the Entrepreneurial Firm," Journal of Management Studies 44(7): 1107-1124 (November).

Langlois, Richard N. 2013. "The Institutional Revolution: A Review Essay," The Review of Austrian Economics(in press). 
Lazonick, William. 1990. Competitive Advantage on the Shop Floor. Cambridge: Harvard University Press.

Libecap, Gary. 1989. Contracting for Property Rights. New York: Cambridge University Press.

Mahoney, James and Kathleen Thelen. 2010. "A Theory of Gradual Institutional Change," in James Mahoney and Kathleen Thelen, eds., Explaining Institutional Change: Ambiguity, Agency, and Power. New York: Cambridge University Press, pp. 1-37.

Maitland, Frederic William. 1897. Domesday Book and Beyond: Three Essays in the Early History of England. Cambridge: Cambridge University Press.

Mantoux, Paul. 1961. The Industrial Revolution in the Eighteenth Century. London: Jonathan Cape.

Marglin, Stephen A. 1974. "What Do Bosses Do?," Review of Radical Political Economy 6: 33-60.

McCloskey, D. N. 1972. "The Enclosure of Open Fields: Preface to a Study of Its Impact on the Efficiency of English Agriculture in the Eighteenth Century," The Journal of Economic History 32(1): 15-35.

McCloskey, D. N. 1975a. "The Economics of Enclosure: A Market Analysis," in William N. Parker and Eric L. Jones, eds., European Peasants and Their Markets. Princeton: Princeton University Press, pp. 123-160.

McCloskey, D. N. 1975b. "The Persistence of English Common Fields," in William N. Parker and Eric L. Jones, eds., European Peasants and Their Markets. Princeton: Princeton University Press, pp. 73-119.

McCloskey, D. N. 1976. "English Open Fields as Behavior Towards Risk," Research in economic history 1(1): 124-170. 
McCloskey, D. N. 1997. "The Good Old Coase Theorem and the Good Old Chicago School: Comment on the Medema-Zerbe Paper," in Steven G. Medema, ed., Coasean Economics: The New Institutional Economics and Law and Economics. Boston: Kluwer Publishing, pp. 239-248.

McCloskey, D. N. 2010. Bourgeois Dignity: Why Economics Can't Explain the Modern World. Chicago: University of Chicago Press.

McCloskey, D. N. and John Nash. 1984. "Corn at Interest: The Extent and Cost of Grain Storage in Medieval England," The American Economic Review 74(1): 174-187.

Miceli, Thomas J. and Kathleen Segerson. 2007. "Punishing the Innocent Along with the Guilty: The Economics of Individual Versus Group Punishment," The Journal of Legal Studies 36(1): 81-106.

Milgrom, Paul, Douglass C. North and Barry R. Weingast. 1990. "The Role of Institutions in the Revival of Trade: The Law Merchant, Private Judges, and the Champagne Fairs," Economics and Politics 2: 1-23 (March ).

Mitchell, B. R. 1988. British Historical Statistics. Cambridge: Cambridge University Press.

Mokyr, Joel. 2002. The Gifts of Athena: Historical Origins of the Knowledge Economy. Princeton: Princeton University Press.

North, Douglass C. 1981. Structure and Change in Economic History. New York: Norton.

North, Douglass C. 1990. Institutions, Institutional Change and Economic Performance. New York: Cambridge University Press.

North, Douglass C. 2005. Understanding the Process of Economic Change. Princeton: Princeton University Press. 
North, Douglass C. and Robert Paul Thomas. 1971. "The Rise and Fall of the Manorial System: A Theoretical Model," The Journal of Economic History 31(4): 777-803.

Olson, Mancur. 1993. "Dictatorship, Democracy, and Development," The American Political Science Review 87(3): 567-576.

Ostrom, Elinor. 1990. Governing the Commons: The Evolution of Institutions for Collective Action. Cambridge: Cambridge University Press.

Pollard, Sidney. 1963. "Factory Discipline in the Industrial Revolution," Economic History Review 16: 254-271 (December).

Pomeranz, Kenneth. 2001. The Great Divergence: China, Europe, and the Making of the Modern World Economy. Princeton: Princeton University Press.

Richardson, Gary. 2005. "The Prudent Village: Risk Pooling Institutions in Medieval English Agriculture," The Journal of Economic History 65(2): 386-413.

Ruttan, Vernon W. and Yujiro Hayami. 1984. "Toward a Theory of Induced Institutional Change," The Journal of Development Studies 20(4): 203-223.

Ruxton, Graeme D. 2002. "The Possible Fitness Benefits of Striped Coat Coloration for Zebra," Mammal Review 32(4): 237-244.

Seebohm, Frederic. 1905. The English Village Community. London: Longmans, Green.

Smith, Henry E. 2000. "Semicommon Property Rights and Scattering in the Open Fields," The Journal of Legal Studies 29(1): 131-169.

Szostak, Rick. 1989. "The Organization of Work: The Emergence of the Factory Revisited," Journal of Economic Behavior \& Organization 11(3): 343-358. 
Temin, Peter and Louis Galambos. 1987. The Fall of the Bell System: A Study of Prices and Politics. New York: Cambridge University Press.

Thirsk, Joan. 1964. "The Common Fields," Past \& Present 29: 3-25.

Ure, Andrew. 1861. The Philosphy of Manufactures. London: G. H. Bohn.

Vietor, Richard H. K. 1994. Contrived Competition. Cambridge: Harvard University Press.

Vinogradoff, Paul. 1892. Villainage in England: Essays in English Mediaeval History. Oxford: Clarendon Press.

Ward-Perkins, Bryan. 2005. The Fall of Rome: And the End of Civilization. Oxford: Oxford University Press.

Williamson, Oliver E. 1980. "The Organization of Work: A Comparative Institutional Assessment," Journal of Economic Behavior and Organization 1(1): 5-38.

Williamson, Oliver E. 1985. The Economic Institutions of Capitalism. New York: The Free Press.

Williamson, Oliver E. 1991. "Comparative Economic Organization: The Analysis of Discrete Structural Alternatives," Administrative Science Quarterly 36(2): 269-296.

Wordie, J. R. 1983. "The Chronology of English Enclosure, 1500-1914," Economic History Review 36(4): 483-505 